\title{
МОДЕЛЮВАННЯ ОПТИМАЛЬНОГО РОЗПОДІЛУ КОШТІВ ДЛЯ ЗМЕНШЕННЯ ІНВЕСТИЦІЙНИХ РИЗИКІВ В УМОВАХ ТРАНСФОРМАЦЙНОЇ ЕКОНОМІКИ
}

\section{MODELING THE OPTIMAL DISTRIBUTION TO REDUCE INVESTMENT RISKS IN THE CONDITIONS OF TRANSFORMATIONAL ECONOMY}

В сучасних умовах економічна діяльність суб'єктів господарювання пов'язана 3 ризиками. Успіх діяльності великою мірою залежить від можливості управління та нівелювання ризиків. В сучасний час дана проблема є однією із значущих в економіці - вона викликає великий інтерес серед різних вчених $i$ дослідників $i$, безумовно, заслуговує комплексного вивчення.

Ризик - ие дії та можливості, пов'язані з подоланням невизначеності в ситуації вибору, в процесі здійснення яких існує можливість розрахувати передбачувану імовірність досягнення визначеного результату, а також можливі втрати та відхилення від поставленої мети.

Інвестиційний ризик характеризує ймовірність виникнення непередбачених фінансових втрат, його рівень при оціниі визначається як відхилення очікуваних доходів від інвестування від середньої або розрахункової величини. Тому оцінка інвестиційних ризиків завжди пов'язана з оцінкою очікуваних доходів та їх втрат. Однак, оцінка ризику - прочес суб'єктивний. Скільки б не існувало математичних моделей розрахунку кривої ризику $i$ точної його величини, у кожному конкретному випадку інвестор сам повинен визначити ризик вкладень в дане підприємство.

В даній статті розглянуто принциипи утворення інвестиційних ризиків, основні їх групи та окреслено ключові групи ризиків, які впливають на інвестиційний проект: фінансовий, кредитний, ринковий та ризик ліквідності. 3 а звітністю обраного підприємства, яке потребує інвестицій, було чисельно визначено виділені групи ризиків, використовуючи різні підходи та методології. Для оптимального розподілу коштів, враховуючи існуючу ризиковість було обрано пробіт-модель для визначення потенційного дефолту інвестиційного проекту, щзо включає в себе розподіл ймовірностей виникнення кожного виду ризику у проекті в иілому.

Щоб усунути дані ризики було розв'язано задачу оптимізачії, яка включає можливість регулювання залученими коштами, спрямованими на погашення ризикової частки кожного виду таким чином, щзоб загальна ймовірність банкрутства розглянутого інвестиційного проекту була мінімальною.

Ключові слова: інвестиційні ризики, інвестиційний проект, фінансовий ризик, кредитний ризик, ризик ліквідності, ринковий ризик, пробіт-модель, дефолт, оптимальний розподіл коштів. 
In modern conditions of economic activity of economic entities involve risks. Success largely depends on the ability of the management and mitigation of risks. In modern times this problem is one of the most important in the economy - it is of great interest among various scholars and researchers and certainly deserves a comprehensive study.

The risk is the possibilities that are associated with overcoming uncertainty in a situation of choice, in implementation of which it is possible to calculate the implied probability of achieving a certain result, as well as possible losses and deviations from the goal.

Investment risk describes the probability of unforeseen financial loss, its level in the assessment is defined as the deviation of the expected income from the investment of the average or calculated values. Therefore, the assessment of investment risk is always associated with the assessment of expected revenues and their losses. However, risk assessment is a subjective process. Whatever existed mathematical models for calculating the risk curve and its exact magnitude, in each case, the investor needs to determine the risk of investment in the company.

This article describes the principles of formation of investment risks, their main groups and identified the key groups of risks affecting the project: financial, credit, market and liquidity risk. Reporting of the selected companies, which requires investment, were numerically identified groups of risks using a variety of approaches and methodologies. For optimal allocation, given existing risk was elected probity model to determine the potential default of the investment project, including the distribution of probabilities of occurrence of each type of risk in the project as a whole.

To address these risks, we solved the optimization problem, which includes the ability to control funds raised were directed to the repayment risk of the share of each type so that the total probability of bankruptcy of the investment project was minimal.

Keywords: investment risks, investment project, financial risk, credit risk, liquidity risk, market risk, probity model, default, optimal distribution of funds.

Вступ. На шляху до глобалізації будь-яка компанія стикається 3 недостатнім забезпеченням матеріальними ресурсами, що спонукає до залучення додаткових коштів - інвестицій. Інвестування у всіх його формах $\mathrm{i}$ типах пов'язане з ризиком, які потрібно мінімізувати.

Інвестиційний ризик має складну структуру, за рахунок різноманітних компонентів, він по суті являє собою імовірність недотримання прибутку під час виконання певних інвестиційних проектів. Однак, оцінка ризику — процес суб'єктивний. Побудова економіко-математичної моделі, яка буде спрямована на оптимальний розподіл коштів, що виділяються на зменшення сумарного ризику інвестиційного проекту в результаті реалізації ризикових подій є однією з важливих та актуальних задач при реалізації інвестиційних проектів.

Для моделювання інвестиційних ризиків необхідно виконати такі завдання:

- виділити ключові групи інвестиційних ризиків

- визначити методи оцінки ризиків

- оцінити та обрахувати інвестиційні ризики для конкретного підприємства

- зменшити загальний ризик інвестиційного проекту за рахунок оптимального розподілу додаткових коштів, які будуть інвестовані в даний проект.

На сьогоднішній день тема інвестиційного ризику стає все більш актуальною, тож нею займаються вітчизняні та зарубіжні науковці. Серед 
найвагоміших досліджень слід виділити роботи таких вчених, як С. М. Ілляшенко, Т. В. Мацибора [3], В. В. Вітлінський, Г. Ю. Панікар [5], О. М. Мозговий, О. С. Коцюба [2], А. О. Старостіна, Т. В. Майорова, М. І. Диба [6] та ін. Зазначені автори розглядали питання інвестиційного ризику, класифікацію, методи оцінки та регулювання. Однак досі відсутні універсальні методики, які можливо адаптувати під потреби кожного конкретного підприємства.

Постановка завдання. Об'єктом ризику є грошові інтереси інвесторів, що вкладають в певній формі капітал в інвестиційний проект. Тому побудова економіко-математичної моделі, яка буде спрямована на оптимальний розподіл коштів, для зменшення кожного виду ризиків та загального ризику всього проекту, щоб збільшити виграш від інвестицій, є завданням цього дослідження.

Методологія. У процесі дослідження використано методи оцінки ризиків для інвестиційного проекту. Було вибрано, відповідно до обраної галузі такі ризики для знаходження: фінансовий, кредитний, ризик ліквідності, та ринковий ризик. Для знаходження ймовірності дефолту інвестиційного проекту було застосовано пробіт-модель. Оптимальний розподіл коштів знайдений за допомогою інструментарію програмного пакету Mathcad.

Результати досліджень. Побудова математичних моделей, що дозволяють краще досліджувати динаміку процесів інвестування з урахуванням наявних факторів ризику, привертає увагу як науковців-теоретиків, так i фінансових менеджерів, які застосовують на практиці кількісну оцінку прибутковості і ризику окремого інвестиційного проекту. В даний час особливо актуальним є моделювання інвестиційних проектів 3 використанням сучасного апарату теорії випадкових процесів та засобів інтелектуального аналізу даних, що дозволяють по новому оцінювати інвестиційну привабливість підприємств, галузей економіки, регіонів і навіть окремих країн. Така робота важлива i для інвесторів, які цікавляться все більш якісними методами оцінки прибутковості i ризику інвестиційних проектів, і для регулюючих органів влади, яких цікавить можливість впливу на інвестиції таким чином, щоб вони якнайкраще відповідали цілям розвитку економіки країни [2].

Розглянемо ситуацію коли на підприємстві існують ризики, які можуть привести до його банкрутства. Для зменшення ризиків залучаються інвестиції, які необхідно розподілити таким чином, щоб звести до мінімуму сумарний ризик проекту. Для оцінки ризику в цілому візьмемо пробіт-модель, яка буде обчислювати ймовірність дефолту підприємства при певному сумарному ризикові часток ризику певного виду.

На наш погляд, найбільш вдала класифікація інвестиційних ризиків наводиться в книзі В. А. Чернова.

Для класифікації інвестиційних ризиків використовуються дві ознаки: 1) джерела виникнення ризиків; 2) причини виникнення та можливості усунення.

Залежно від джерела виникнення інвестиційний ризик підрозділяють: на діловий ризик; фінансовий ризик; ризик, пов'язаний 3 купівельною 
спроможністю; кредитний ризик, процентний ризик; ризик ліквідності; ринковий і випадковий ризик.

Діловий ризик - ступінь невизначеності, що пов'язана із створенням доходів від інвестицій, достатніх, щоб розплатитися зі всіма інвесторами, які надали кошти.

Фінансовий ризик - ступінь невизначеності, що пов'язана з комбінацією позикових і власних засобів, що використовуються для фінансування компанії або власності: чим більше частка позикових коштів, тим вище фінансовий ризик.

Ризик, пов'язаний 3 купівельною спроможністю, що обумовлено інфляційними процесами та зниженням купівельної спроможності національної валюти.

Процентний ризик - це ступінь невизначеності на рівні курсів цінних паперів, викликана зміною ринкових процентних ставок; зі зростанням процентних ставок курси цінних паперів, особливо 3 фіксованим доходом, знижуються, і навпаки.

Кредитний ризик - наявний або потенційний ризик для надходжень i капіталу, який виникає через неспроможність сторони, що взяла на себе зобов'язання, виконати умови будь-якої фінансової угоди із банком або в інший спосіб виконати взяті на себе зобов'язання.

Ризик ліквідності - це неможливість розплатитися в повному обсязі перед позичальниками за рахунок грошових коштів і активів.

Ринковий ризик - ймовірність негативного зміни ринкової вартості активів підприємства в результаті впливу різних макро, мезо і мікро факторів (політична, економічна і соціальна нестабільність та ін.).

Випадковий ризик - ризик, що виникає $з$ подій, більшою частиною чи цілком несподіваного, яке має значну і зазвичай негайне вплив на вартість відповідних інвестицій.[9]

В залежності від причин виникнення і можливості усунення розрізняють диверсифікований (несистематичний) та недиверсифікований (систематичний) ризик, поєднання яких дає сукупний ризик

Диверсифікований ризик пов'язаний, як правило, 3 внутрішніми факторами, тобто залежить від діяльності самої організації. Він може бути усунутий в результаті диверсифікації. Диверсифікація означає свідомий i обгрунтований підбір інвестицій у такі проекти, які забезпечать їх прийнятну прибутковість.

Недиверсифікований ризик обумовлений зовнішніми факторами (війна, інфляція, політичні події тощо), тобто не залежить від діяльності організації.

Обравши галузь туризму для інвестування, було проаналізовано що найбільший вплив на результат інвестицій в даній сфері мають такі ризики як: фінансовий, кредитний, ризик ліквідності, та ринковий ризик. Це пов’язане 3 
тим що в підприємствах цієї галузі основна частка коштів є залучена та велику роль відіграє ринкова ситуація в даний момент. Тоді сумарний ризик в даному випадку буде складатись 3 фінансового, кредитного, ризику ліквідності та ринковому ризиках. [6]

При нульових початкових ризиках ймовірність дефолту теж буде набувати нульового значення, при збільшенні ризиків збільшуватиметься сумарний ризик а отже, і ймовірність даного господарюючого суб'єкта.

Отже, отримаємо функцію $f(z)$-яка показує ймовірність банкрутства, та функцію $Z\left(k_{1}, k_{2}, k_{3}, k_{4}\right)$, яка показує сумарний ризик.

$$
\begin{gathered}
f(z)=\frac{1}{\sqrt{2 \pi}} \cdot e^{-\frac{1}{2} \cdot z^{2}} \rightarrow \min \\
Z\left(k_{1}, k_{2}, k_{3}, k_{4}\right)=\left(1-k_{1}\right) \cdot z_{1}+\left(1-k_{2}\right) \cdot z_{2}+\left(1-k_{3}\right) \cdot z_{3}+\left(1-k_{4}\right) \cdot z_{4}
\end{gathered}
$$

Де

$z_{1}$ - фінансовий ризик;

$z_{2}-$ кредитний ризик;

$z_{3}-$ ризик ліквідності;

$z_{4}-$ ринковий ризик;

$k_{1}$ - частка коштів, яка буде інвестована на погашення фінансового ризику;

$k_{2}$ - частка коштів, яка буде інвестована на погашення кредитного ризику;

$k_{3}$ - частка коштів, яка буде інвестована на погашення ризику ліквідності;

$k_{4}$ - частка коштів, яка буде інвестована на погашення ринкового ризику.

Оскільки ми розподіляєм одну суму на всі ризики, сума всіх часток має бути від [0;1]:

$$
0 \leq k_{1}+k_{2}+k_{3}+k_{4} \leq 1
$$

Отже, отримуємо критерій оптимальності

$$
f\left(k_{1}, k_{2}, k_{3}, k_{4}\right)=\frac{1}{\sqrt{2 \pi}} \cdot e^{-\frac{1}{2} \cdot\left(\left(1-k_{1}\right) \cdot z_{1}+\left(1-k_{2}\right) \cdot \mathbf{z}_{2}+\left(1-k_{3}\right) \cdot \mathbf{z}_{3}+\left(1-k_{4}\right) \cdot \mathbf{z}_{4}\right)^{2}} \rightarrow \text { min }
$$

Та обмеження:

$$
\left\{\begin{array}{c}
0 \leq k_{1}+k_{2}+k_{3}+k_{4} \leq 1 \\
0<k_{1}<1 \\
0<k_{2}<1 \\
0<k_{3}<1 \\
0<k_{4}<1
\end{array}\right.
$$

Для моделювання за допомогою пробіт-функції, для початку необхідно обчислити всі інвестиційні ризик для конкретного підприємства. 
Вибір підприємства для дослідження було зроблено на інвестиційному порталі Inventure, де розміщають пропозиції щодо інвестування. Було обрано Приватне акціонерне товариство "Готель "Дніпро" номер ЄДРПОУ 02573547. Дане підприємство розмістило оголошення про необхідність залучення інвестиційних коштів в розмірі 150000 грн. [8]

За допомогою бухгалтерської звітності за період 3 01.01.2017 по 31.12.2017 та даних розміщених на сайті залучення інвесторів обчислюємо конкретні значення ризиків:[7]

Фінансовий ризик

$$
\begin{gathered}
z_{1}=p \frac{W A C C}{E V A} \\
E V A=N O P A T-W A C C \cdot C E
\end{gathered}
$$

NOPAT (Net Operating Profit Adjusted Taxes) - 825

WACC (Weight Average Cost of Capital) - WACC $=\frac{3000+5868}{240014}=0,00369$

$\mathrm{CE}($ Capital Employed $)-10745+88957=99702$

EVA (Economic Value Added) EVA $=825-0,00369 *(10745+88957)=$ 457,099

$$
z_{1}=\frac{0,00369}{457.099}=0,242
$$

Кредитний ризик

$$
z_{2}=0,063 \cdot K_{1}+0,092 \cdot K_{2}+0,057 \cdot K_{3}+0,0014 \cdot K_{4}
$$

$\mathrm{K}_{1}$ - оборотний капітал/сума активів;

$\mathrm{K}_{2}$ - прибуток від реалізації / сума активів;

$\mathrm{K}_{3}$ - нерозподілений прибуток / сума активів;

$\mathrm{K}_{4}$ - власний капітал / позиковий капітал.

Оборотний капітал - 19701

Сума активів - 248535

Прибуток від реалізації - 30174

Нерозподілений прибуток - 1348

Власний капітал -240618

Позиковий капітал $-3000+5868=8868$

$$
\begin{aligned}
Z_{2} & =0,063 \cdot \frac{19701}{248535}+0,092 \cdot \frac{30174}{248535}+0,057 \cdot \frac{1348}{248535}+0,057 . \\
\frac{240618}{3000+5868} & =0,215865
\end{aligned}
$$

Ризик ліквідності: 


$$
z_{3}=\frac{a}{b}
$$

a - Поточні зобов'язання -2917

b - Оборотні активи - 9701

$$
z_{3}=\frac{2917}{9701}=0,3
$$

Ринковий ризик:

$$
z_{4}=0,1 \cdot R_{1}+1,4 \cdot R_{2}+3,3 \cdot R_{3}+0,6 \cdot R_{4}+R_{5}
$$

$\mathrm{R}_{1}$ - власні оборотні кошти/сума активів;

$\mathrm{R}_{2}$ - чистий прибуток/сума активів;

$\mathrm{R}_{3}$ - прибуток до оподаткування і виплати відсотків/сума активів;

$\mathrm{R}_{4}$ - ринкова вартість акцій/позиковий капітал;

R5 - виручка/сума активів.

Власні оборотні кошти $-9701-566=9125$

Сума активів - 9701

Чистий прибуток 825

Прибуток до оподаткування і виплати відсотків - 825

Ринкова вартість акцій - 564

Позиковий капітал $5868+3000=8868$

Виручка - 351

$$
z_{4}=0,1 \cdot \frac{9701-576}{9701}+1,4 \cdot \frac{825}{9701}+3,3 \cdot \frac{825}{9701}+0,6 \cdot \frac{564}{5868+3000}+\frac{351}{9701}=0,42579
$$

Отже, обчисливши всі ризики, які ми будемо брати до уваги можемо записати остаточну оптимізаційну модель із заданими обмеженнями.

$$
\begin{gathered}
f\left(k_{1}, k_{2}, k_{3}, k_{4}\right)=\frac{1}{\sqrt{2 \pi}} \cdot e^{-\frac{1}{2} \cdot\left(\left(1-k_{1}\right) \cdot 0,242+\left(1-k_{2}\right) \cdot 0,216+\left(1-k_{3}\right) \cdot 0,3+\left(1-k_{4}\right) \cdot 0,426\right)^{2}} \rightarrow \min \\
\left\{\begin{array}{c}
0 \leq k_{1}+k_{2}+k_{3}+k_{4} \leq 1 \\
0<k_{1}<1 \\
0<k_{2}<1 \\
0<k_{3}<1 \\
0<k_{4}<1
\end{array}\right.
\end{gathered}
$$

Висновки. Інвестиційні ризики загрожують зменшенням прибутків або ймовірними збитками. Тому під час прийняття рішень 3 питань щодо інвестиційної діяльності керівництво підприємств має обов'язково враховувати вплив всіх видів інвестиційних ризиків. Інвестиційні ризики об'єктивні для усіх суб'єктів економіки, які займаються інвестиційною діяльністю. Для того, щоб 
інвестиційна діяльність була ефективною, усі можливі види інвестиційних ризиків повинні бути старанно вивчені економічним суб'єктом, оскільки невиправданий ризик може призвести до банкрутства підприємства, a перестрахування - до втраченого зиску і навіть до втрати ринку.

В даній статті показано визначення ймовірності дефолту конкретного інвестиційного проекту через пробіт-модель за допомогою моделювання інвестиційних ризиків, які детально розглянуто і обчислено за допомогою різних підходів та методологій. Після визначення ймовірностей кожного виду ризиків, нам вдалось оптимізувати частки на погашення цих ризиків, щоб ймовірність банкрутства даного інвестиційного проекту була мінімальною. В наступному дослідженні по цій темі планується розглянути інвестиції в розрізі часу, та отримання прибутку в наступних періодах.

Дане дослідження може бути використане інвестором для оцінки ризику при вкладанні ресурсів в підприємство, та знаходження основних ризикоутворюючих факторів, які можуть зменшені за допомогою коштів, які будуть інвестовані.

\section{Література:}

1. Закон України «Про інвестиційну діяльність» : за станом на 18 грудня 2017 p. Верховна Рада України. - Офіц. Вид. - К.: Парлам. вид-во, 2000. - 14 с. (Бібліотека офіційних видань).

2. Коцюба О.С. Моделювання ризику інвестиційної діяльності/ О.С. Коцюба // Фінанси України. - 2004. - № 7. - С.56-67

3. Орехов Н.А. Математические методы и модели в экономике: Учеб. пособие для вузов / Орехов Н.А., Левин А.Г., Горбунов Е.А.; Под ред. проф. Н.А. Орехова. - Москва: ЮНИТИ-ДАНА, 2004. - с. 219-223.

4. Мацибора Т. В. Ризик як складова інвестиційного процесу/ Мацибора Т. В. // Економіка АПК. - 2008. - № 11. - С. 90-92.

5. Панікар Г.Ю. Інвестиційні ризики: їх характеристика та вплив на процес іноземного інвестування / Панікар Г.Ю. // Вісник Київського національного університету імені Тараса Шевченка. - 2000. - №15: Міжнародні відносини. - С. 71-74.

6. Диба М. I. Основні джерела фінансових ризиків / М. І. Диба // Фінанси України. - 2009. - № 5. - С. 101-108.

7. Річна фінансова звітність е6мітента Приватного акціонерного товариства "Готель "Дніпро" [Електронний ресурс]. - Режим доступу: https://smida.gov.ua/db/emitent/02573547

8. Инвестиционные предложения: инвестиционные проекты, стартапы, продажа бизнеса [Електронний ресурс]. - Режим доступу: https://inventure.com.ua

9. Чернов В.А. Анализ коммерческого риска/ Под ред. М.И. Баканова. - Москва: Финансы и статистика, 1998. -502 с. 